\title{
Determinan Kejadian Berat Badan di Bawah Garis Merah (BGM) pada Balita
}

\author{
Rusmilawaty, Tri Tunggal, Isrowiyatun Daiyah* \\ Poltekkes Kemenkes Banjarmasin \\ ”Email korespondensi: owizdaiyah1006@gmail.com
}

\begin{tabular}{l} 
Article Info \\
\hline Article history: \\
Submitted:2020-05-13 \\
Accepted:2020-05-18 \\
Published: 2020-05-28 \\
\hline Keywords: \\
Underweight Red Line; \\
Toddlers; Exclusive \\
Breastfeeding History, \\
Feeding Patterns,
\end{tabular}

Article history:

Submitted:2020-05-13

Accepted:2020-05-18

-

Toddlers; Exclusive

Feeding Patterns,

The prevalence of under-five children under-red line in the working area of Karang Intan I Public Health Center is very high and continues to increase. In 2016 it was $10.3 \%$, and in 2017 it was $12.2 \%$. This study aimed to determine the factors associated with the occurrence of body weight below the red line in toddlers in the working area of Karang Intan 1. This study used analytic survey methods with crosssectional approach. This study population was all toddlers, amounting to 801 people and a sample of 267 people with the purposive sampling method. The instrument used a questionnaire. The test used was the Chi-Square statistical test. The results showed a relationship between the history of exclusive breastfeeding $(\rho=0.001)$, feeding patterns $(\rho=0,000)$, history of infectious diseases $(\rho=0.042)$, maternal visits to Integrated healthcare center (Posyandu) $(\rho=0.002)$, family economic status $(\rho=0,0151)$ with the occurrence of body weight below the red line (BGM) in infants. Conclusion: there is a relationship between exclusive breastfeeding, eating care, history of infectious diseases, maternal visits to the Posyandu, family economic status towards the occurrence of body weight below the red line in toddlers. Feeding patterns is a significant determinant of BGM events. These determinants can be used for screening the development and growth of infants.

\section{ABSTRAK}

Kata kunci:

Bawah Garis Merah (BGM); Balita; Riwayat ASI Eksklusif, Pola makan.

\begin{abstract}
Prevalensi balita Bawah Garis Merah BGM di wilayah kerja Puskesmas Karang Intan I sangat tinggi dan terus meningkat. Pada tahun 2016 sebesar $10,3 \%$ dan tahun 2017 sebesar 12,2\%. Penelitian ini bertujuan untuk mengetahui faktor yang berhubungan dengan kejadian berat badan BGM pada balita di wilayah kerja Puskesmas Karang Intan 1 Kabupaten Banjar. Penelitian ini menggunakan metode survei analitik dengan pendekatan Cross Sectional. Populasi dalam penelitian ini adalah seluruh balita yang berjumlah 801 orang dan sampel berjumlah 267 orang dengan metode purposive sampling. Instrument menggunakan kuesioner. Uji yang digunakan adalah uji Chi-Square. Hasil penelitian menunjukkan ada hubungan riwayat pemberian ASI Eksklusif $(\rho=0,001)$, pola asuh makan $(\rho=0,000)$, riwayat penyakit infeksi $(\rho=0,042)$, kunjungan ibu ke Posyandu $(\rho=0,002)$, status ekonomi keluarga $(\rho=0,0151)$ dengan kejadian berat badan di bawah garis merah (BGM) pada balita.Kesimpulan: ada hubungan riwayat pemberian ASI Eksklusif, pola asuh makan, riwayat penyakit infeksi, kunjungan ibu ke Posyandu, status ekonomi keluarga dengan kejadian berat badan di bawah garis merah (BGM) pada balita. Pola Asuh makan merupakan faktor utama determinan pada kejadian BGM.
\end{abstract}




\section{PENDAHULUAN}

Hasil Survei Demografi dan Kesehatan Indonesia (SDKI), menunjukkan bahwa Angka Kematian Balita (AKABA) mengalami penurunan dari tahun ke tahun pada periode 1991-2015 yaitu pada tahun 2015 sebesar 26,2 per 1.000 kelahiran hidup, juga sudah memenuhi target Millennium Development Goals (MDGs) 2015 sebesar 32 per 1.000 kelahiran hidup. ${ }^{1}$ Pada tahun 2017 menunjukkan bahwa angka kebatan balita (AKABA) sebesar 32 per 1.000 kelahiran hidup. ${ }^{2}$

Berdasarkan data Dinas KesehatanProvinsi, AKABA di Provinsi Kalimantan Selatan tahun 2017 yaitu mencapai 1 per 1.000 Kelahiran Hidup. Faktor risiko utama kematian balita adalah penyakit infeksi, diare, gizi buruk dan gizi kurang. ${ }^{2}$

Status gizi balita dapat dipantau dengan menimbang anak setiap bulan dan dicocokkan dengan Kartu Menuju Sehat (KMS). ${ }^{3}$ Salah satu masalah gizi berdasarkan pemantauan status gizi dengan KMS pada balita adalah Bawah Garis Merah (BGM) yaitu anak dengan berat badan kurang menurut umur dibandingkan dengan standar, yang diketahui secara visual dengan melihat plot dalam KMS berada di bawah garis merah. ${ }^{4}$

Dua faktor penyebab masalah gizi yang menentukan besarnya presentasi status gizi balita dengan BGM yaitu faktor langsung dan tidak langsung. Faktor penyebab secara langsung adalah konsumsi makanan yang tidak memenuhi prinsip gizi seimbang (pemberian ASI eksklusif) dan penyakit infeksi yang terkait dengan tingginya kejadian penyakit menular dan buruknya kesehatan lingkungan. ${ }^{5}$ Sedangkan faktor penyebab tidak langsung yaitu ketahanan pangan di keluarga, pola pengasuhan anak (pola asuh makan, pola asuh kesehatan seperti pemantauan kesehatan anak yang berkaitan dengan imunisasi dan keaktifan kunjungan ibu ke posyandu, dan pola konsumsi), serta pelayanan kesehatan dan kesehatan lingkungan. ${ }^{6}$ Faktor penyebab tidak langsung yang lain yaitu ketidaktahuan akan hubungan makanan dan kesehatan, prasangka buruk terhadap bahan makanan tertentu, adanya kebiasaan atau pantangan yang merugikan, kesukaan yang berlebihan terhadap jenis makanan, jarak kelahiran yang terlalu rapat, dan status ekonomi. ${ }^{7}$

Berdasarkan data Dinas Kesehatan Provinsi Kalimantan Selatan tahun 2017, Kabupaten Banjar menempati urutan ke-2 tertinggi balita yang mengalami BGM yaitu berjumlah1.627 kasus $(4,7 \%)$ dari sasaran 47.593 balita. Jumlah kasus balita yang mengalami BGM di Wilayah Kerja Puskesmas Karang Intan 1 terjadi peningkatan dari tahun tahun 2016 terdapat 109 kasus $(10,35 \%)$ dari sasaran1.043 balita dan tahun 2017 mencapai 125 kasus (12,21\%) dari sasaran 1.024 balita. Peringkat tersebut naik dari tahun sebelumnya yang berada pada posisi ke-4 tertinggi menjadi peringkat ke-2 tertinggi setelah Puskesmas Telaga Bauntung $(13,21 \%)$ atau 45 balita mengalami BGM. ${ }^{8}$

Berdasarkan studi pendahuluan yang telah dilakukan oleh peneliti di Karang intan 1 pada hari Rabu tanggal 12 Desember2018 dari 10 ibu balita yang diwawancarai langsung terdapat 9 balita (90\%) tidak ASI Eksklusif, 6 balita (60\%) yang pola asuh makannya kurang, 7 balita $(70 \%)$ mengalami penyakit infeksi, seperti: diare dan demam pada 3 bulan terakhir, 2 ibu (20\%) tidak aktif membawa anaknya kunjungan ke Posyandu, karena kesibukan orang tua bekerja, dan 7 balita (70\%) penghasilan keluarga kurang dari UMP Kalimantan Selatan tahun 2018. Penelitian ini bertujuan untuk menganalisis determinan kejadian berat badan bawah garis merah (BGM) pada balita di Wilayah Kerja Puskesmas Karang intan 1 Kabupaten Banjar. 


\section{METODE PENELITIAN}

Jenis penelian ini menggunakan rancangan survey analitik dengan pendekatan cross sectional. Populasi dalam penelitian ini adalah seluruh ibu balita beserta balitanya di wilayah kerjaPuskesmas Karang Intan 1 Kabupaten Banjar tahun 2019 berjumlah 801 balita. Sampel dalam penelitian ini adalah seluruh ibu balita beserta balitanya di wilayah kerjaPuskesmas Karang Intan 1 Kabupaten Banjar tahun 2019 berjumlah 267 orang. Teknik pengambilan sampel pada penelitian ini menggunakan purposive sampling. Pengumpulan data dilakukan berdasarkan data primer melakukan wawancara menggunakan kuesioner yang diadopsi dan sudah dilakukan pengujian validitas reabilitas. Variabel independen yang diteliti riwayat pemberian ASI, pola asuh makan, riwayat penyakit infeksi, kunjungan ibu ke Posyandu, dan status ekonomi keluarga. Penelitian ini dilakukan dari bulan November 2018 - Mei 2019. Analisis bivariat menggunakan uji Chi Square $\left(X^{2}\right)$ pada tingkat kemaknaan adalah (a) 0,05.

\section{HASIL PENELITIAN}

1. Karakteristik Responden

Tabel 1. Distribusi Responden berdasarkan Pendidikan, Umur Balita dan Berat Badan Lahir Di Wilayah KerjaPuskesmas Karang Intan 1

\begin{tabular}{lcc}
\hline \multicolumn{1}{c}{ Variabel } & Frekuensi & Persentase (\%) \\
\hline Pendidikan Ibu & & \\
Tinggi & 41 & 15,4 \\
Menengah & 47 & 17,6 \\
$\quad$ Dasar & 179 & 67,0 \\
Umur Balita & & \\
$\quad$ 1-3 tahun & 75 & 28,1 \\
$\quad$ >3-5 tahun & 192 & 71,9 \\
Berat Badan Lahir & & \\
>2500 gram & 143 & 53,6 \\
<2500 gram & 124 & 46,4 \\
\hline
\end{tabular}

Sumber: Data Primer, 2019

Dari tabel 1 dapat diketahui bahwa sebagian besar ibu yang memiliki balita BGM berpendidikan dasar $(70,0 \%)$, sebagian besar balita BGM berumur $>3-5$ tahun $(90,8 \%)$ dan sebagian besar balita BGM mempunyai Berat badan lahir $>2500$ gram $(52,3 \%)$.

2. Variabel Univariat

Tabel 2. Distribusi Frekuensi Responden berdasarkan Variabel yang diteliti di Wilayah Kerja Puskesmas Karang Intan 1

\begin{tabular}{lcc}
\hline \multicolumn{1}{c}{ Variabel } & Frekuensi & Persentase (\%) \\
\hline Kejadian BGM & & \\
$\quad$ Tidak & 174 & 65,2 \\
$\quad$ Ya & 93 & 34,8 \\
Riwayat pemberian ASI eksklusif & & \\
$\quad$ Ya & 121 & 45,3 \\
$\quad$ Tidak & 146 & 54,7 \\
Pola asuh makan & & \\
$\quad$ Baik & 110 & 41,2 \\
$\quad$ Kurang & 157 & 58,8 \\
\hline
\end{tabular}




\begin{tabular}{lcc}
\hline \multicolumn{1}{c}{ Variabel } & Frekuensi & Persentase (\%) \\
\hline Riwayat penyakit infeksi & & \\
$\quad$ Tidak Ada & 153 & 41,2 \\
$\quad$ Ada & 114 & 58,8 \\
Kunjungan ibu ke posyandu & & \\
$\quad$ Aktif & 172 & 64,4 \\
$\quad$ Tidak Aktif & 95 & 35,6 \\
Status ekonomi keluarga & & \\
$\quad$ Z UMP & 86 & 32,2 \\
< UMP & 181 & 67,8 \\
\hline
\end{tabular}

Sumber: Data Primer, 2019

Berdasarkan tabel 2 menunjukkan bahwa dari 267 orang responden,jumlah balita BGM yaitu sebanyak 93 orang (34,8\%), ibu yang tidak memberikan ASI Eksklusif yaitu sebanyak 146 orang $(54,7 \%)$, pola asuh makan yang kurang yaitu sebanyak 157 orang $(58,8 \%)$, jumlah balita dengan riwayat penyakit infeksi yaitu sebanyak 153 orang $(58,8 \%)$, ibu yang tidak aktif membawa balitanya ke posyandu yaitu sebanyak 95 orang $(35,6 \%)$ dan status ekonomi keluarga <UMP (kurang dari Rp 2.453.671/bulan) yaitu sebanyak 181 orang $(67,8 \%)$.

3. Variabel Bivariat

Tabel 3 Hubungan Riwayat Pemberian ASI Eksklusif, Pola Asuh Makan, Riwayat Penyakit Infeksi, Kunjungan Ibu ke Posyandu dan Status Ekonomi Keluarga dengan Kejadian BGM Pada Balita di Wilayah Kerja Puskesmas Karang Intan 1

\begin{tabular}{|c|c|c|c|c|c|c|c|}
\hline \multirow{3}{*}{ Variabel } & \multicolumn{4}{|c|}{ Kejadian BGM } & \multirow{3}{*}{ Nilai $\rho$} & \multirow{3}{*}{ OR } & \multirow{3}{*}{$\begin{array}{c}\mathbf{R} \\
\text { Square }\end{array}$} \\
\hline & \multicolumn{2}{|c|}{ Tidak } & \multicolumn{2}{|c|}{ Ya } & & & \\
\hline & $\mathbf{n}$ & $\%$ & $\mathbf{n}$ & $\%$ & & & \\
\hline \multicolumn{8}{|c|}{ Riwayat pemberian ASI eksklusif } \\
\hline Ya & 92 & 76,0 & 29 & 24,0 & 0,001 & 2,8 & 0,208 \\
\hline Tidak & 82 & 56,2 & 64 & 43,8 & & & \\
\hline \multicolumn{8}{|l|}{ Pola asuh makan } \\
\hline Baik & 98 & 89,1 & 12 & 10,9 & 0,000 & 8,5 & 0,419 \\
\hline Kurang & 76 & 48,4 & 81 & 51,6 & & & \\
\hline \multicolumn{8}{|c|}{ Riwayat penyakit infeksi } \\
\hline Tidak Ada & 112 & 73,2 & 41 & 26,8 & 0,042 & 1,2 & 0,195 \\
\hline Ada & 62 & 54,4 & 52 & 45,6 & & & \\
\hline \multicolumn{8}{|c|}{ Kunjungan ibu ke posyandu } \\
\hline Aktif & 128 & 74,4 & 44 & 25,6 & 0,002 & 2,5 & 0,261 \\
\hline Tidak Aktif & 46 & 48,4 & 49 & 51,6 & & & \\
\hline \multicolumn{8}{|c|}{ Status ekonomi keluarga } \\
\hline$\geq$ UMP & 66 & 76,7 & 20 & 23,3 & 0,015 & 1,6 & 0,167 \\
\hline$<$ UMP & 108 & 59,7 & 73 & 40,3 & & & \\
\hline
\end{tabular}

Sumber: Data primer, 2019

Berdasarkan uji statistik didapatkan nilai $\rho<0,05$ maka hipotesis penelitian diterima. Hal ini berarti ada hubungan yang signifikan antara riwayat pemberian asi eksklusif, pola asuh makan, riwayat penyakit infeksi, kunjungan ibu ke posyandu dan status ekonomi keluarga dengan kejadian berat badan di Bawah Garis Merah (BGM) pada balita. Faktor bebas yang utama dan 
determinasi terdapat pada pola asuh makan dengan nilai $R$ Square 0,419 yang berarti hubungan sedang. Pola asuh makan mempunyai peluang yang besar terhadap kejadian BGM dengan nilai OR 8,5.

\section{PEMBAHASAN}

Berdasarkan hasil uji statistik didapatkan hasil ada hubungan yang signifikan antara riwayat pemberian ASI Eksklusif dengan kejadian BGM pada balita di Wilayah kerja Puskesmas Karang Intan 1 Kabupaten Banjar tahun 2019. OR menunjukkan nilai 2,5. Hasil ini berarti ibu yang tidak memberikan ASI Eksklusif mempunyai risiko sebesar 2 kali lebih besar mengalami kejadian BGM pada anak balita dibandingkan dengan ibu yang memberikan ASI Eksklusif kepada anak balitanya.

Jika seorang bayi tidak diberikan ASI Eksklusif dan diganti dengan susu formula, maka bayi tidak mendapatkan kekebalan, dan sebagian besar menyebabkan kekurangan gizi. Dengan tidak adanya zat antibodi, maka bayi akan mudah terserang berbagai macam penyakit dan meningkatkan angka kematian bayi. ${ }^{9}$ Hasil penelitian ini sejalan dengan hasil lain yang menyatakan terdapat hubungan riwayat pemberian ASI eksklusif dengan balita gizi kurang di Wilayah Kerja Puskesmas Cebongan. Nilai OR sebesar 3,4 berarti balita yang mendapat ASI ekslusif mempunyai peluang 3 kali lebih besar menjadikan balita mempunyai gizi baik daripada balita yang tidak diberikan ASI eksklusif. ${ }^{10}$

Banyak faktor yang mempengaruhi status gizi anak balita yang mendapatkan ASI Eksklusif yaitu salah satunya penyakit infeksi. Pernyataan ini sejalan dengan hasil penelitian yang menyatakan ada hubungan yang signifikan antara penyakit infeksi dengan status gizi anak balita di wilayah kerja Puskesmas Gambesi Kota Ternate. ${ }^{11}$

Berdasarkan hasil uji statistik didapatkan hasil ada hubungan yang signifikan antara pola asuh makan dengan kejadian BGM pada balita di Wilayah kerja Puskesmas Karang Intan 1 Kabupaten Banjar tahun 2019. OR menunjukkan nilai 8,1. Hasil ini berarti pola asuh makan yang kurang mempunyai risiko sebesar 8 kali lebih besar mengalami kejadian BGM pada anak balita dibandingkan dengan pola asuh makan yang baik.

Pada penelitian ini sebagian besar responden memberikan makanan kepada anak yang tidak beraneka ragam tetapi yang penting mengenyangkan dan anak mau memakannya, memberikan makan kepada anak sesuai keinginannya (tidak teratur), dan kurang memedulikan situasi saat makan yang terpenting anak mau makan. Penelitian ini sejalan dengan hasil penelitian lain menderita BGM dibandingkan anak balita yang pola makannya baik. ${ }^{12}$

Pada ibu balita dengan pola asuh makan baik tetapi masih ada yang mengalami kejadian BGM pada balitanya karena kejadian BGM tidak hanya dipengaruhi oleh pola asuh makan saja tetapi dipengaruhi oleh beberapa faktor yang lainnya, seperti faktor pendapatan yang kurang menyebabkan tidak sanggupnya menyediakan makanan yang bergizi, sehingga hal ini akan mempengaruhi status gizi anak. Karena tingkat konsumsi makanan ditentukan oleh kualitas dan kuantitas makanan. Pernyataan ini sejalan sesuai dengan penelitian lain yang menyatakan ada hubungan antara pendapatan rendah dengan status gizi anak balita BGM. ${ }^{13}$

Teknik atau cara memasak yang salah juga akan mempengaruhi kadar gizi atau kandungan zat gizi pada bahan makanan seprti sayur dan buah. Misalnya, vitamin $\mathrm{C}$ dan kelompok vitamin $\mathrm{B}$ adalah jenis vitamin yang bisa larut dalam air dan rusak bila terekspos cahaya dan terkena suhu tinggi. Akibatnya, kedua jenis vitamin tersebut bisa hilang dari makanan bila kita menggunakan cara memasak yang tidak tepat. $^{14}$ 
Penelitian Hilmiyah dan Afriyani (2018) menunjukkan bahwa alasan keaktifan ibu dalam kunjungan posyandu adalah untuk melakukan pemantauan status gizi sehingga dengan dilakukan pemantauan yang rutin diharapakan balita memiliki status gizi yang baik dan dapat dilakukan deteksi dini terhadap status gizi yang kurang. Batita BGM tidak selalu menderita gizi buruk tapi menjadi indikator awal mengalami masalah gizi. Karena pentingnya penilaian status gizi, maka perlu dilakukan identifikasi pola konsumsi. ${ }^{15,16}$

Pola makan yang baik terdiri dari konsumsi makanan yang berkualitas yaitu konsumsi makanan yang sehat dan bervariasi, serta konsumsi makanan yang cukup dari segi kuantitas diikuti dengan menerapkan perilaku makan yang benar. Jika hal ini diterapkan, makan akan menghasilkan status gizi anak yang normal. ${ }^{17}$

Berdasarkan hasil uji statistik didapatkan hasil ada hubungan yang signifikan antara riwayat penyakit infeksi dengan kejadian BGM pada balita di Wilayah kerja Puskesmas Karang Intan 1 Kabupaten Banjar tahun 2019. OR menunjukkan nilai 2,291 . Hasil ini berarti balita yang memiliki riwayat penyakit infeksi mempunyai risiko sebesar 2 kali lebih besar mengalami kejadian BGM dibandingkan dengan balita yang tidak memiliki riwayat penyakit infeksi.

Penyakit infeksi akan menghambat pertumbuhan melalui penurunan asupan makan dan penyerapan zat gizi, sebab anak yang sakit nafsu makannya akan turun bahkan ada yang tidak mau makan sehingga nutrisi yang masuk kedalam tubuh juga kurang, hilangnya zat gizi, peningkatan kebutuhan metabolik dan penghambat transfer zat gizi kejaringan sehingga asupan makanan untuk kebutuhan tidak terpenuhi menyebabkan daya tahan tubuh anak balita melemah yang akhirnya mengalami kejadian BGM. Hasil penelitian ini didukung penelitian lainnya yang menyatakan bahwa terdapat hubungan antara penyakit infeksi dengan status gizi anak balita di Puskesmas Awal Terusan. Nilai OR sebesar 5,7 berarti anak balita yang menderita penyakit infeksi berisiko 6 kali menderita BGM dibandingkan anak balita yang tidak menderita penyakit infeksi. ${ }^{12}$ Asupan ASI juga bisa mencegah dari penyakit pneumonia. ${ }^{18}$

Pada balita yang tidak memiliki riwayat penyakit infeksi tetapi masih ada yang mengalami kejadian BGM pada balita disebabkan karena faktor yang lain seperti pola pengasuhan, dan tingkat ketahanan pangan. Hal ini juga dikemukan oleh penelitian lainnya ada hubungan antara pola asuh ibu dengan kejadian balita BGM di wilayah kerja Puskesmas Tatah Makmur Kabupaten Banjar. Ada hubungan antara ketahanan pangan tingkat keluarga dengan status gizi balita di Desa Gondangwinangun. ${ }^{19,20}$

Berdasarkanhasil uji statistik didapatkan hasil ada hubungan yang signifikan antara kunjungan ibu kePosyandu dengan kejadian BGM pada balita di Wilayah kerja Puskesmas Karang Intan 1 Kabupaten Banjar tahun 2019. OR menunjukkan nilai 3,0. Hasil ini berarti ibu yang tidak aktif melakukan kunjungan ke Posyandu mempunyai risiko sebesar 3 kali lebih besar mengalami kejadian BGM pada balitanya dibandingkan dengan ibu yang aktif melakukan kunjungan ke Posyandu.

Ibu yang tidak aktif berkunjung keposyandu mengakibatkan ibu kurang mendapatkan informasi mengenai pentingnya status gizi balita, tidak mendapat dukungan dan dorongan dari petugas kesehatan apabila ibu mempunyai permasalahan kesehatan pada balitanya, serta pemantauan pertumbuhan dan perkembangan balita yang tidak dapat terpantau secara optimal, karena pemantauan pertumbuhan balita dapat dipantau melalui KMS. Berdasarkan hasil wawancara, ibu mengatakan tidak sempat membawa balitanya berkunjung kePosyandu dikarenakan harus bekerja, sibuk dan tidak sempat ditambah dengan anak rewel. Hasil penelitian ini sejalan dengan penelitian lainnya yang menyatakan ada hubungan partisipasi ibu 
keposyandu dengan status gizi anak balita di Puskesmas Awal Terusan. Nilai OR sebesar 6,6 berarti ibu yang rutin hadir keposyandu berisiko 7 kali mempunyai status gizi anak balita yang tidak BGM dibandingkan ibu yang tidak rutin hadir keposyandu. ${ }^{12}$

Pada ibu yang aktif melakukan kunjungan ke Posyandu tetapi masih ada yang mengalami kejadian BGM pada balitanya disebabkan karena kurangnya penyuluhan secara rutin dalam kegiatan Posyandu terkait status gizi. Berdasarkan faktanya di Posyandu desa Mali-mali salah satunya kegiatan seperti penyuluhan memang belum rutin diberikan oleh tenaga kesehatan, seperti Bidan, dan yang dilakukan kader juga selama ini ialah melakukan penimbangan, menyediakan makanan untuk balita dan setelah itu ibu balita pulang tanpa membawa ilmu terkait gizi balita sehingga menyebabkan ibu kurang mengerti tentang perkembangan status gizi balitanya. Pernyataan ini sejalan dengan hasil penelitian lain yang menyatakan ada hubungan yang signifikan antara pendidikan kesehatan tentang gizi dengan status gizi balita di Surakarta. ${ }^{10}$

Berdasarkan hasil uji statistik didapatkan hasil ada hubungan yang signifikan antara status ekonomi keluarga dengan kejadian BGM pada balita di Wilayah kerja Puskesmas Karang Intan 1 Kabupaten Banjar tahun 2019. OR menunjukkan nilai 2,2. Hasil ini berarti status ekonomi keluarga yang < UMP mempunyai risiko sebesar 2 kali lebih besar mengalami kejadian BGM dibandingkan dengan status ekonomi keluaga yang $\geq U M P$.

Status ekonomi keluarga <UMP atau rendah akan mengalami kesulitan dalam memenuhi kebutuhan makanan yang bergizi pada balita, jika suatu keluarga memiliki pendapatan yang besar serta cukup untuk memenuhi kebutuhan gizi anggota keluarga maka akan menjamin kebutuhan gizi pada balita akan terpenuhi, sehingga balita tidak akan mengalami BGM dan sebaliknya, jika pendapatan keluarga rendah maka dapat mempengaruhi penyediaan dan pemilihan jenis atau keanekaragaman makanan, sehingga akan menyebabkan terjadinya balita dengan berat badan di BGM. Pernyataan ini sesuai dengan teori yang menyatakan bahwa tidak dapat disangkal bahwa penghasilan keluarga akan turut menentukan hidangan yang disajikan untuk keluarga sehari-hari, baik kualitas maupun jumlah makanan. ${ }^{7}$ Hasil penelitian ini juga sesuai dengan penelitian lainnya yang menyatakan bahwa terdapat hubungan antara tingkat pendapatan keluarga dengan kejadian balita gizi kurang di Wilayah Kerja Puskesmas Cebongan. Nilai OR sebesar 5,7 berarti tingkat pendapatan keluarga lebih dari UMR mempunyai peluang 6 kali lebih besar menjadikan balita dengan gizi baik dari pada tingkat pendapatan keluarga kurang dari UMR. ${ }^{10}$ Ada hubungan antara status sosial ekonomi dengan status gizi anak balita di Puskesmas Awal Terusan. Nilai OR sebesar 10,2 berarti anak balita yang mempunyai status sosial ekonomi nya rendah berisiko 10 kali menderita BGM dibandingkan anak balita yang status sosial ekonominya tinggi. ${ }^{12}$ Pada ibu balita yang status ekonomi keluarga $\geq$ UMP tetapi masih ada balitanya yang mengalami kejadian BGM hal ini disebabkan karena kebutuhan dalam keluarga tidak hanya pangan untuk balita saja, tetapi masih banyak hal lain yang harus dipenuhi sehingga penghasilan juga harus dibagi-bagi untuk memenuhi kebutuhan hidup sekeluarga. Hasil penelitian oleh putri dkk menunjukan terdapat hubungan pendapatan keluarga dengan status gizi balita. Diikuti dengan hasil analisis multivariat yang dilakukan menunjukan bahwa pendapatan keluarga merupakan salah satu faktor yang berhubungan dengan status gizi balita ${ }^{21}$

\section{SIMPULAN DAN SARAN}

Penelitian ini menyimpulkan ada hubungan antara riwayat pemberian ASI eksklusif, pola asuh makan, riwayat penyakit infeksi, kunjungan ibu ke posyandu dan 
status ekonomi keluarga dengan kejadian berat badan di bawah garis merah (BGM) pada balita. Penelitian ini menyarankan agar promosi ASI eksklusif ditingkatkan, memperbaiki pola asuh makan balita, memaksimalkan pemberian Vitamin $A$, bagi anak secara rutin untuk mencegah infeksi, dan memastikan setiap bulan ibu melakukan kunjungan posyandu, serta memprioritaskan bantuan pemberian makanan tambahan bagi keluarga miskin dan status ekonomi keluarga yang rendah.

\section{UCAPAN TERIMA KASIH}

Peneliti menyampaikan terima kasih kepada Direktur Poltekkes Kemenkes Banjarmasin dan Ketua Jurusan Kebidanan Poltekkes Kemenkes Banjarmasinyang telah mendukung penelitian ini, Kepala Dinas Kesehatan Kabupaten Banjar yang memberikan izin untuk dilakukan penelitian di wilayah Puskesmas Karang Intan I, Ibu Balita yang telah bersedia menjadi responden dalam penelitian ini.

\section{DAFTAR PUSTAKA}

1. Kementerian Kesehatan R.I. Profil Kesehatan Indonesia Tahun 2016. Jakarta: Kementerian Kesehatan R.I.; 2017.

2. Kementerian Kesehatan R.I. Profil Kesehatan Indonesia Tahun 2017. Jakarta: Kementerian Kesehatan R.I.; 2018.

3. Proverawati A, Asfuah S. Gizi untuk Kebidanan. Yogyakarta: Nuha Medika; 2009.

4. Sandjaja A. Kamus Gizi: Pelengkap Kesehatan Keluarga. Jakarta: Penerbit Buku Kompas; 2009.

5. Irianto K. Gizi Seimbang dalam Kesehatan Reproduksi = Balanced Nutrition in Reproductive Health. Bandung: Alfabeta; 2014.

6. Marmi, Rahardjo K. Asuhan Neonatus Bayi, Balita, dan Anak Prasekolah. Jogjakarta: Pustaka Pelajar; 2012.

7. Marimbi H. Tumbuh Kembang Status Gizi dan Imunisasi Dasar Pada Balita. Jogjakarta: Nuha Medika; 2010.

8. Dinas Kesehatan Kabupaten Banjar. Profil Kesehatan Kabupaten Banjar 2017. Martapura: Dinas Kesehatan Kabupaten Banjar; 2018.

9. Astutik RY. Payudara dan Laktasi. Jakarta: Salemba Medika; 2014.

10. Lastanto, Indri H, Cindy A. Analisis Faktor Yang Mempengaruhi Kejadian Balita Gizi Kurang di Wilayah Kerja Puskesmas Cebongan. J Stikes Kusuma Husada. 2014;1(1):114.

11. Harahap SM. Pengaruh Perilaku Ibu Terhadap Kejadian Bawah Garis Merah (BGM) Pada Anak Balita Di Wilayah Kerja Puskesmas Sayur Matinggi Kabupaten Tapanuli Selatan [Internet]. Universitas Sumatera Utara; 2014. Available from: http://repository.usu.ac.id/handle/123456789/45095

12. Destriatania S, Febry F. Determinan Kejadian Anak Balita di Bawah Garis Merah di Puskesmas Awal Terusan. J IImu Kesehat Masy [Internet]. 2016;7(1):48-63. Available from: http://www.jikm.unsri.ac.id/index.php/jikm

13. Sriyani. Faktor yang Berhubungan dengan Kejadian Balita Bawah Garis Merah (BGM) di Wilayah Kerja Puskesmas Tatah Makmur Kabupaten Banjar. Poltekkes Kemenkes Banjarmasin; 2018.

14. Jevita jhodit JJ, Wibowo H. Balita Bawah Garis Merah di Wilayah Kerja Puskesmas Cukir Diwek Jombang. IImu kebidanan [Internet]. 2015;1(2):1-7. Available from: http://journal.stikespemkabjombang.ac.id/index.php/jikeb/article/download/73/71/

15. Hilmiyah K, Afriyani LD. Hubungan Kepatuhan Dalam Kunjungan Posyandu Terhadap Status Gizi Balita Di Desa Mlilir Kecamatan Bandungan Kabupaten Semarang. Indones J Midwifery. 2018;1(2):85-8.

16. Safitri YA, Darmaningtyas IP. Pola Makan Batita "Z" Dengan Status Gizi Bgm (Bawah Garis Merah) Di Puskesmas Ketawang Kabupaten Malang. J Hesti Wira Sakti. 2016;4(1):94-100. 
17. Wahyudi BF, Indarwati R, Wahyudi BF. Analisis faktor yang berkaitan dengan kasus gizi buruk pada balita. J Pediomaternal. 2015;3(1):83-91.

18. Linda. Hubungan Pemberian Asi Eksklusif dan Bayi Berat Lahir Rendah (BBLR) dengan Kejadian Pneumonia pada Balita di Wilayah Puskesmas Kamonji. J Bidan Cerdas. 2018;1(1):27-33.

19. Nurhalimah. Faktor Yang Mempengaruhi Pemberian ASI Eksklusif Di Wilayah Kerja Puskesmas Aranio Kabupaten Banjar. Poltekkes Kemenkes Banjarmasin; 2018.

20. Sari G, Lubis G, Edison E. Hubungan Pola Makan dengan Status Gizi Anak Usia 3-5 tahun di Wilayah Kerja Puskesmas Nanggalo Padang 2014. J Kesehat Andalas [Internet]. 2016 Aug 11;5(2). Available from: http://jurnal.fk.unand.ac.id/index.php/jka/article/view/528

21. Putri RF, Sulastri D, Lestari Y. Faktor-Faktor yang Berhubungan dengan Status Gizi Anak Balita di Wilayah Kerja Puskesmas Nanggalo Padang. J Kesehat Andalas [Internet]. 2015 Jan 1;4(1). Available from: http://jurnal.fk.unand.ac.id/index.php/jka/article/view/231 